\title{
Trace Metal Contamination in Urban Sediments in Port Louis, Mauritius
}

\author{
Roshan Teewary Ramessur ${ }^{*}$, Kishore Boodhoo \\ Faculty of Science, University of Mauritius, Reduit, Mauritius \\ Corresponding Author : ramessur@uom.ac.mu
}

Copyright (C) 2013 Horizon Research Publishing. All rights reserved.

\begin{abstract}
The aim of this study was to assess $\mathrm{Cu}, \mathrm{Pb}$ and $\mathrm{Zn}$ contamination in estuarine and urban sediments along Grand River North West (GRNW) during 2009-2013. Pb and $\mathrm{Zn}$ were significantly higher in the GRNW estuary though unleaded petrol was introduced since 2002. In fact, the potential sources of $\mathrm{Cu}, \mathrm{Pb}$ and $\mathrm{Zn}$ in the urban estuarine sediments at GRNW were considered to arise from brakedust, road runoff and galvanized road furniture causing significant quantities to be trapped in coastal sediments with increasing vehicles. The mean concentration of $\mathrm{Pb}$ and $\mathrm{Zn}$ in the urban sediments along GRNW were however still below the limits of 700 and $2500 \mathrm{mg} \mathrm{kg}^{-1}$ quoted for contaminated sediments adopted from the draft standards ( $24 \%$ clay and $10 \%$ organic matter by weight) from Netherlands. The concentration of $\mathrm{Cu}, \mathrm{Pb}$ and $\mathrm{Zn}$ were also greatest in the more urbanised lower reaches of the Grand River Bay. $\mathrm{Pb}$ remained significantly positively correlated with $\mathrm{Zn}$ indicating that the cycling of $\mathrm{Pb}$ and $\mathrm{Zn}$ were linked indicating a common traffic related source for $\mathrm{Pb}$ and $\mathrm{Zn}$ in the urban sediments in GRNW. $\mathrm{Pb}$ was significantly lower at 5\% significance level upstream, downstream, estuary during summer 2013 compared to summer 2010 and could be due to floods which occurred in summer 2013. Cu was also significantly positively correlated with $\mathrm{Pb}$ confirming the traffic related common source (brakedust and vehicle emissions) in the urban sediments of GRNW.
\end{abstract}

Keywords Copper, Lead, Zinc, Sediment, Contamination, Correlation

\section{Introduction}

The first decade of the $21^{\text {st }}$ century was 10 years of change for the environment, as new environment issues emerged and existing issues evolved. From the beginning of the industrial revolution, pollution has become an increasing concern. It has been observed in cities that there is lead, zinc and copper enrichment in both soil and sediment as a result of the increase in road runoff from fuel combustion as well as brake and tyre wear [1-5]. During recent years Mauritius (1850 $\mathrm{km}^{2}, 20^{\circ} \mathrm{S}, 57^{\circ} \mathrm{E}$ ) has undergone landuse changes due to rapid urbanization and increase in road networks which contribute to sediment quality degradation. The urban and coastal environments of Mauritius are suffering ever-increasing impact from anthropogenic activities [6]. Most recently, trace metal pollution has become a matter of great concern and pose a contamination threat in both soil and surface sediments as the number of vehicles on the island in 2013 increased to more than 400000 even though unleaded petrol was introduced in 2002. To support this point, potential high concentrations of dissolved metals particularly lead and zinc were found along GRNW and its causes have been associated to urban and road runoff [7-9]. A major fraction of the trace metals introduced into the estuaries is found to be associated with sediments, whereby they constitute a danger for aquatic life. The sediment environment provides a long term record of the effects of anthropogenic discharges, such as industrial and domestic effluents and is an area where impacts often occur before effects are manifest in the water column. In contrast to the strong temporal and spatial variability in the aqueous concentrations of contaminants, sediments integrate contaminant concentrations over time and that by focusing on sediments the number of samples needed in contamination assessment can be reduced [10]. Trace metals concentrations in aquatic ecosystems are usually monitored by measuring their concentrations in water, sediments and biota which generally exist in the low levels in water and attain considerable concentration in sediments and biota [12-14]. Sediments are important sinks for various trace metals and also play a significant role in the remobilisation of contaminants in aquatic systems under favorable conditions with standard values as shown in Table 1 for contaminated sediments $(24 \%$ clay and $10 \%$ organic matter by weight) in the Nertherlands [4]. $\mathrm{Pb}, \mathrm{Cu}$ and $\mathrm{Zn}$ in sediments close to motorways are high and traffic related with fuel combustion $(\mathrm{Pb})$, brake dust $(\mathrm{Cu})$ and tyre wear $(\mathrm{Cu}$ and $\mathrm{Zn}$ ) as $\mathrm{ZnO}$ is added as an activator during the vulcanizing process of tyres and $\mathrm{Zn}$ additives used as engine 
lubricants [5, 14-17]. A number of articles around the world have shown that trace metals have considerably increased due to human related activities such as industrialisation, urbanisation and mining activities [18-26]. $\mathrm{Cu}$ values reported for the crust range between $24-55 \mathrm{mg} \mathrm{kg}^{-1}$ while total concentration of $\mathrm{Cu}$ in sediments are expected to be between $20-30 \mathrm{mg} \mathrm{kg}^{-1}$ [20]. The sources of the metals in urban effluents include corrosion of water pipes and brake linings $(\mathrm{Cu})$ and road runoff with heavy traffic. These trace metals enter estuaries both from feeder rivers and from direct discharges and tend to be trapped in estuaries and accumulate in sediments [21].

The major areas for environmental and public concern in Mauritius are pollution of estuaries and lagoons. Sources of input of trace metals (in particular, $\mathrm{Cu}, \mathrm{Pb}$ and $\mathrm{Zn}$ ) in Mauritius in recent years include industrial effluents, urban and road runoff, sewage sludge, landfill leachates including scrap metal and solid waste leachates. In this paper, three trace metals $(\mathrm{Cu}, \mathrm{Pb}$ and $\mathrm{Zn})$ surface sediments along the north west coast along GRNW were assessed and any common linking in biogeochemical cycles investigated during the wet and dry months during the period 2009- 2013 using atomic absorption spectrometry. The following investigations were made:

- Are there any significant trace metal deposition $(\mathrm{Cu}$, $\mathrm{Pb}$ and $\mathrm{Zn}$ ) in urban sediments with the introduction of unleaded petrol in 2002 and an increase in the number of vehicles?

- Are there any significant correlations and a common influential linking between $\mathrm{Cu}, \mathrm{Pb}$ and $\mathrm{Zn}$ in the urban sediments along GRNW?

Table 1. Draft standards for contaminated sediments, SPM and trace metal concentration in sediments in rivers and estuaries [4, 20 23-26].

\begin{tabular}{|c|c|c|c|c|c|}
\hline & $\begin{array}{c}\text { Target } \\
\mathrm{mg} \mathrm{kg}-1\end{array}$ & $\begin{array}{c}\text { Standard } \\
\mathrm{mg} \mathrm{kg}-1\end{array}$ & $\begin{array}{c}\text { Limit } \\
\mathrm{mg} \mathrm{kg}-1\end{array}$ & River & Estuary \\
\hline $\mathrm{Cu}$ & 25 & 70 & 400 & & $45-281$ \\
\hline $\mathrm{Pb}$ & 50 & 125 & 700 & $\begin{array}{c}22-484 \\
5-60\end{array}$ & $12-64$ \\
\hline $\mathrm{Zn}$ & 180 & 750 & 2500 & $\begin{array}{c}75-1264 \\
15-230\end{array}$ & $62-470$ \\
\hline
\end{tabular}




\section{Materials and Methods}

\subsection{Sampling Stations}

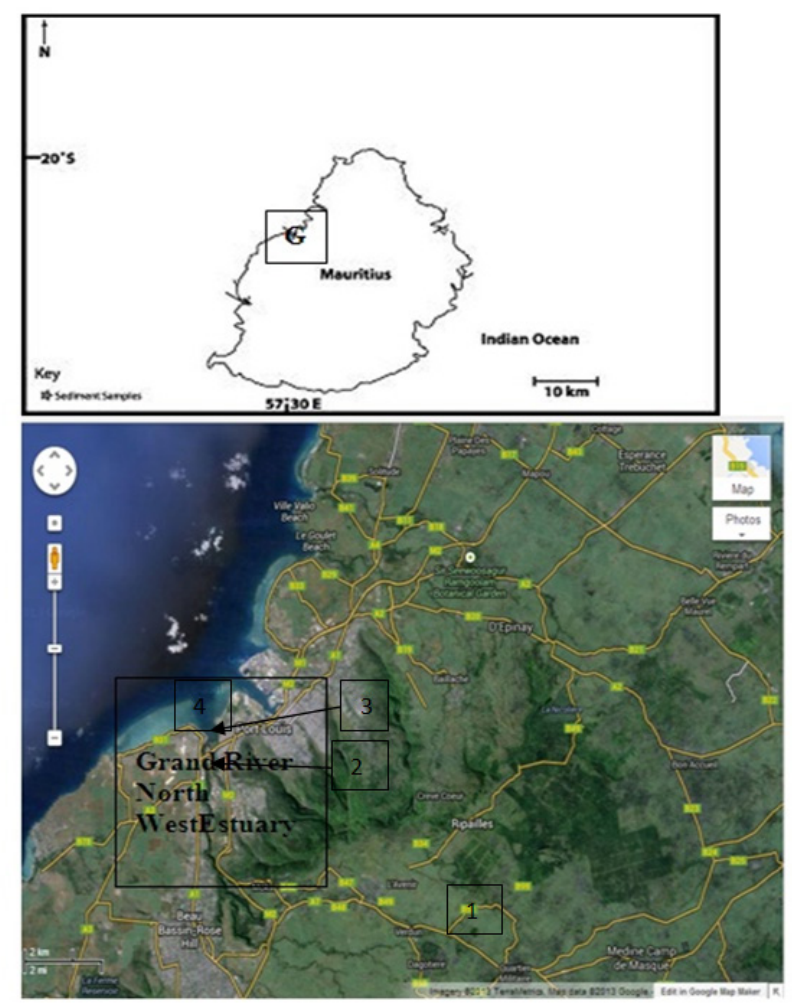

Figure 1. Sampling stations along stations along GRNW in Port Louis area, Mauritius

Station 1 Camp Auguste Station 1 is found upstream along River Cascades in the upper GRNW catchment area and is considered to have the lowest traffic density along the B48. The soil type at Camp Auguste is latosolic red prairie soil.

Station 2 (GRNW-old bridge) Station 2 is found downstream under the GRNW old bridge and now closed, previously used to access Port-Louis from the central west and southwest part of the island. The bridge is in a rusting state, with residential and industrial area bordering the river on one side, the trees and the main road on the other. This was found on the road formerly called as the Beau-Bassin link road.

Station 3 (Estuary at Sable Noir) Station 3 is situated in the southern region of Port Louis and it is found in the midst of intense industrial activities. The estuary indirectly receives roadrunoff from the St.Louis and GRNW rivers and flows through Pailles and Plaine Lauzun industrial and urban area next to the St Louis Generating power station. The annual average rainfall in the Sable Noir area is $1160 \mathrm{~mm}$. The average rainfall at a nearby meteorological station (Fort Williams, Port Louis) were $100 \mathrm{~mm}$ during summer and 25 $\mathrm{mm}$ during winter but exceeded $150 \mathrm{~mm}$ during a flood in March 2013. Boats were seen on such station; therefore it is likely to be a fishing area for people living in the vicinity. Sable Noir is the place where St Louis River discharges its water and mixes with water from Grand River North West and eventually the sea and the water is turbid with high algal content.

Station 4 (Sable Noir Beach) Station 4 is found at the Sable Noir public beach about $100 \mathrm{~m}$ from the estuary of the GRNW, situated near the Martello Tower, receiving water both from GRNW and St Louis River. There is a boat industry just nearby the sampling area. The Sable Noir public beach which is considered as the estuary for the St Louis River can be seen on the opposite side of the estuary.

\subsection{Surface Sediments}

Surface sediment were also collected at 4 stations (upstream, downstream, estuary and lagoon) along GRNW and Grand River Bay. $\mathrm{Cu}, \mathrm{Zn}$, and $\mathrm{Pb}$ were determined in surface sediments using atomic absorption spectrometry. The establishment of stations were directed in a typical aquatic system in Mauritius which could be used as an example in a regional perspective. Sampling was done at a sufficiently high sampling density to ensure data integrity and also to maintain a sufficiently broad spatial coverage to include relatively uncontaminated areas for reference purposes. The potential for a significant degree of localised distributional heterogeneity at each sampling incidence was considered and replicate sampling was done to obtain results within specified confidence limits.

Sediment samples were air dried for 3 days and oven dried at $70^{\circ} \mathrm{C}$ for 1 day. After drying, the sediments were disaggregated and dry sieved using a $63 \mu \mathrm{m}$ sieve as trace metals have affinity for the finer grained mud fraction $(<63 \mathrm{um})$ [27]. The dried sediment leaching were made in triplicate. $0.5 \mathrm{~g}$ of the fine fraction was weighed into a teflon beaker cleaned with nitric acid $(65 \%)$ and deionised water. Analar nitric acid (4ml, $65 \%$, BDH Ltd, U.K) was added to remove most organic matter in the sample followed by $2 \mathrm{~mL}$ hydrofluoric acid and the mixture swirled until the vigorous action stopped. All samples were digested in duplicate using a Milestone microwave digestion system. The samples were then left to cool and the contents filtered into $25 \mathrm{~mL}$ plastic flasks and the volume made up to the mark with deionised water. The extracted solution was then analysed in terms of total $\mathrm{Cu}, \mathrm{Pb}$ and $\mathrm{Zn}$ respectively. A blank consisting of only nitric acid $(4 \mathrm{ml}, 65 \%)$ and hydrofluoric acid $(2 \mathrm{ml})$ and digested in the same way as the samples was also prepared.

\subsection{Trace Metal Analysis in Surface Sediments}

$\mathrm{Cu}, \mathrm{Zn}$ and $\mathrm{Pb}$ were determined in the extracted solution from surface sediments collected during the period September 2009-July 2013 using a UNICAM 929 Atomic Absorption Spectrometer (AAS) (Analytical Technology Inc. 1993). Standards used for calibration for trace metal determination in sediments were prepared from standard $1000 \mathrm{mg} \mathrm{l}^{-1}$ stock solution. The working solutions $\left(10 \mathrm{mg} \mathrm{l}^{-1}\right)$ of each $\mathrm{Cu}, \mathrm{Pb}$ and $\mathrm{Zn}$ were prepared by diluting the stock solution in a $100 \mathrm{ml}$ volumetric flask with deionised water. 
Standards were then prepared in the range of 1.0-4.0 $\mathrm{mg} \mathrm{l}^{-1}$ for $\mathrm{Cu}, \mathrm{Pb}$ and $\mathrm{Zn}$. Flame AAS used for trace metal analysis in surface sediments involved the use of an air-acetylene flame for $\mathrm{Cu}, \mathrm{Zn}$ and $\mathrm{Pb}$ at a wavelength of 324.8, 213.9 and $217.0 \mathrm{~nm}$ respectively. The sample of carrier gas flow rate was maintained between $200-500 \mathrm{ml} \mathrm{min}^{-1}$.

\subsection{Quality Control}

The accuracy and precision of the method was evaluated using three replicate determination of Standard Reference Material SRM 1646a Trace Elements in Estuarine Sediments from National Institute for Science and Technology (USGS 1884, Colorado, U.S.A) which yielded $7.7 \pm 1.2 \mathrm{mg} \mathrm{kg}^{-1}(\mathrm{Cu})$; $40.5 \pm 1.2 \mathrm{mg} \mathrm{kg}^{-1}(\mathrm{Zn}) ; 8.7 \pm 1.3 \mathrm{mg} \mathrm{kg}^{-1}(\mathrm{~Pb})$ compared to certified values of $10.01 \pm 0.34 \mathrm{mg} \mathrm{kg}^{-1}(\mathrm{Cu}), 48.9 \pm 1.6 \mathrm{mg}$ $\mathrm{kg}^{-1}(\mathrm{Zn})$ and $11.7 \pm 1.2 \mathrm{mg} \mathrm{kg}^{-1}(\mathrm{~Pb})$ respectively (mean and standard deviation) as determined using ICP MS by NIST with \% recovery as $76.9 \%, 82.8 \%$ and $74.4 \%$ for $\mathrm{Cu}, \mathrm{Zn}$ and $\mathrm{Pb}$ respectively. The main causes of losses were during the digestion procedure and also included random and systematic sources of uncertainty during analysis using the atomic absorption spectrometer. Necessary corrections and adjustments were made to the data accordingly. The detection limits were $1.1,2.2$ and $1.2 \mathrm{mg} \mathrm{kg}^{-1}$ for $\mathrm{Cu}, \mathrm{Zn}$ and
$\mathrm{Pb}$ respectively. (The limits of detection were taken as $3 \sigma$ of three replicates of the procedural blank digested filter paper ( $3 \mathrm{x}$ standard deviation about the mean).

\section{Results and Discussion}

\subsection{Trace Metals in Surface Sediments}

The linearity for the calibration lines for $\mathrm{Cu}, \mathrm{Pb}$ and $\mathrm{Zn}$ showed correlation coefficient ranging from 0.95-0.99. $\mathrm{Cu}$, $\mathrm{Pb}$ and $\mathrm{Zn}$ in sediments along GRNW exceeded the target values of 25,50 and $180 \mathrm{mg} \mathrm{kg}^{-1}$ respectively at GRNW as shown in Tables 2-4. The mean concentration of $\mathrm{Cu}(732.9 \pm$ $1585.6 \mathrm{mg} \mathrm{kg}^{-1}$ ) in urban downstream sediments along GRNW in summer 2013 can be considered comparable those from contaminated estuarine sediments in industrialized countries [26]. The mean concentration of $\mathrm{Pb}$ and $\mathrm{Zn}$ in the urban sediments in GRNW were however still below the limits of 700 and $2500 \mathrm{mg} \mathrm{kg}^{-1}$ quoted for contaminated sediments adopted from the draft standards (24\% clay and $10 \%$ organic matter by weight) from Netherlands [4] whereas $\mathrm{Cu}$ exceeded the $400 \mathrm{mg} \mathrm{kg}^{-1}$ limits downstream in summer 2013.

Table 2. Mean and Standard Deviation of $\mathrm{Pb}$ during winter 2009 and summer 2010 and 2013 along GRNW.

\begin{tabular}{|c|c|c|c|c|}
\hline Station & $\begin{array}{c}\text { Winter 2009 } \\
\mathrm{mg} \mathrm{kg}\end{array}$ & $\begin{array}{c}\text { Summer 2010 } \\
\mathrm{mg} \mathrm{kg}^{-1}\end{array}$ & $\begin{array}{c}\text { Mean Pb (2009-2010) } \\
\mathrm{mg} \mathrm{kg}^{-1}\end{array}$ & $\begin{array}{c}\text { Summer 2013 } \\
\mathrm{mg} \mathrm{kg}^{-1}\end{array}$ \\
\hline Upstream & $19 \pm 0$ & $19 \pm 2.8$ & $19 \pm 0$ & $4.4 \pm 4.0$ \\
\hline Downstream & $281.9 \pm 59.0$ & $187.2 \pm 56.9$ & $234.4 \pm 66.7$ & $20.4 \pm 14.7$ \\
\hline Estuary & $12.5 \pm 9.3$ & $45.4 \pm 22.8$ & $29.0 \pm 23.3$ & $9.3 \pm 2.0$ \\
\hline Lagoon & $6.1 \pm 4.0$ & $25.8 \pm 30.8$ & $16.0 \pm 13.9$ & $37.7 \pm 26.8$ \\
\hline
\end{tabular}

Table 3. Mean and Standard Deviation of $\mathrm{Zn}$ during winter 2009 and summer 2010 along GRNW.

\begin{tabular}{|c|c|c|c|}
\hline Station & $\begin{array}{c}\text { Winter 2009 } \\
\mathrm{mg} \mathrm{kg}^{-1}\end{array}$ & $\begin{array}{c}\text { Summer 2010 } \\
\mathrm{mg} \mathrm{kg}^{-1}\end{array}$ & $\begin{array}{c}\text { Mean Zn (2009-2010) } \\
\mathrm{mg} \mathrm{kg}^{-1}\end{array}$ \\
\hline Upstream & $101.5 \pm 3.5$ & $99 \pm 14.1$ & $100.2 \pm 1.8$ \\
\hline Downstream & $325.9 \pm 9.8$ & $357.3 \pm 89.2$ & $341.6 \pm 22.2$ \\
\hline Estuary & $245.2 \pm 2.1$ & $327.6 \pm 34.8$ & $286.4 \pm 58.2$ \\
\hline Lagoon & $148.5 \pm 136.0$ & $236.5 \pm 204.5$ & $192.5 \pm 62.2$ \\
\hline
\end{tabular}

Table 4. Mean and Standard Deviation of $\mathrm{Cu}(\mathrm{mg} / \mathrm{kg})$ along GRNW estuary in 2013

\begin{tabular}{|c|c|c|}
\hline & \multicolumn{2}{|c|}{ Mean Cu mg kg-1 } \\
\hline Station & Summer 2013 & Winter 2013 \\
\hline Upstream & $92.0 \pm 12.3$ & $213.4 \pm 301.5$ \\
\hline Downstream & $732.9 \pm 1585.6$ & $79.5 \pm 13.3$ \\
\hline Estuary & $116.1 \pm 86.0$ & $261.6 \pm 150.7$ \\
\hline Lagoon & $37.7 \pm 26.8$ & $51.6 \pm 23.1$ \\
\hline
\end{tabular}


The concentration of $\mathrm{Pb}$ and $\mathrm{Zn}$ in surface sediments along GRNW in summer and winter are shown in Fig 2-3.

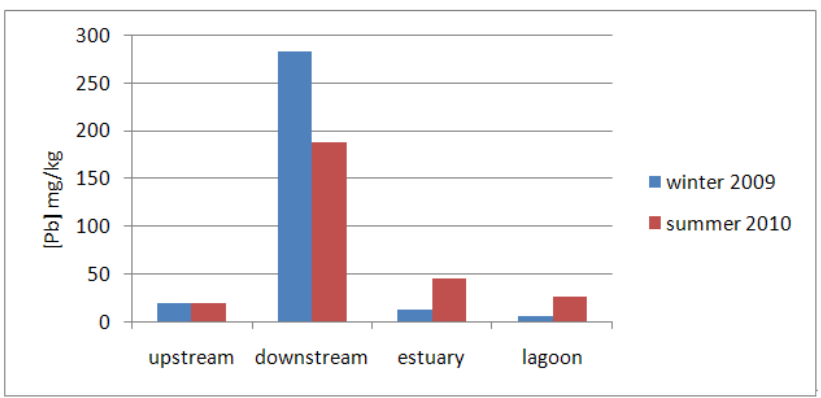

Figure 2. Variation of mean lead concentration during winter 2009 and summer 2010 along GRNW

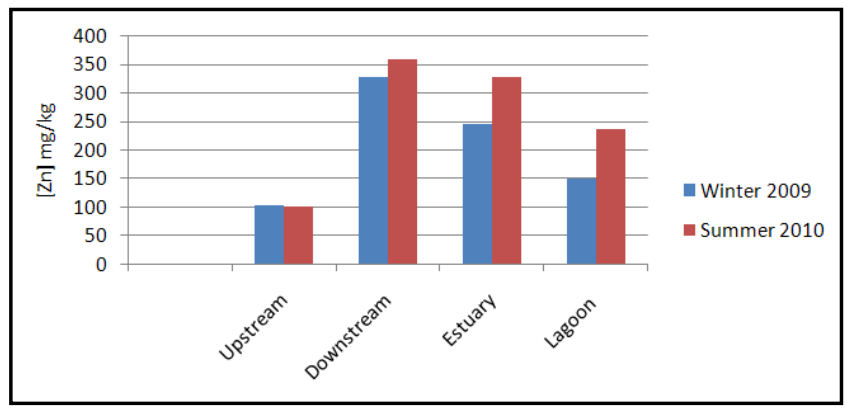

Figure 3. Variation of mean $\mathrm{Zn}$ concentration during winter 2009 and summer 2010 along GRNW

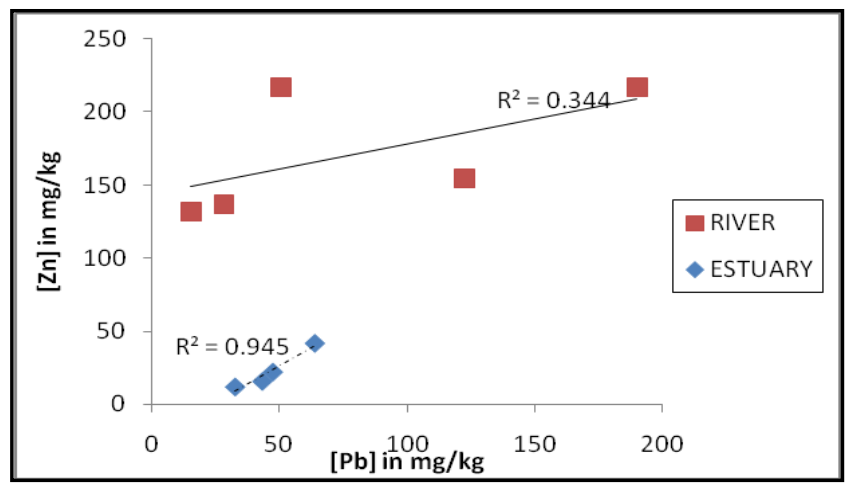

Figure 4. Correlations between $\mathrm{Zn}$ and $\mathrm{Pb}$ at GRNW during the period September 2008 - January 2009.

$\mathrm{Zn}$ and $\mathrm{Pb}$ in the sediments in the GRNW estuary were significantly positively correlated at $5 \%$ significance level $\left(\mathrm{r}^{2}\right.$ $=0.95, \mathrm{n}=5)$ as shown in Fig 4. This shows that the cycling of lead and zinc are linked at the GRNW estuary with a common urban run-off of urban origin from GRNW as urbanization have thus produced significant changes in the sediments of the GRNW estuary as was similarly found for $\mathrm{Zn}$ and $\mathrm{Pb}$ in sediments as previously found in GRNW estuary in 2004 [10].

$\mathrm{Cu}$ and $\mathrm{Pb}$ in the sediments in the GRNW estuary were significantly positively correlated at $5 \%$ significance level $\left(\mathrm{r}^{2}\right.$ $=0.53, \mathrm{n}=5$ ) as shown in Fig 5 indicating a common traffic related source including brake dust $(\mathrm{Cu})$ and vehicle emissions $(\mathrm{Pb})$ in urban sediments of GRNW as was found in inner city canal sediments in the city of Delft, the Netherlands [20]. $\mathrm{Pb}$ was significantly lower at 5\% significance level upstream, downstream, estuary during summer 2013 compared to summer 2010 and could be due to floods which occurred in summer 2013.

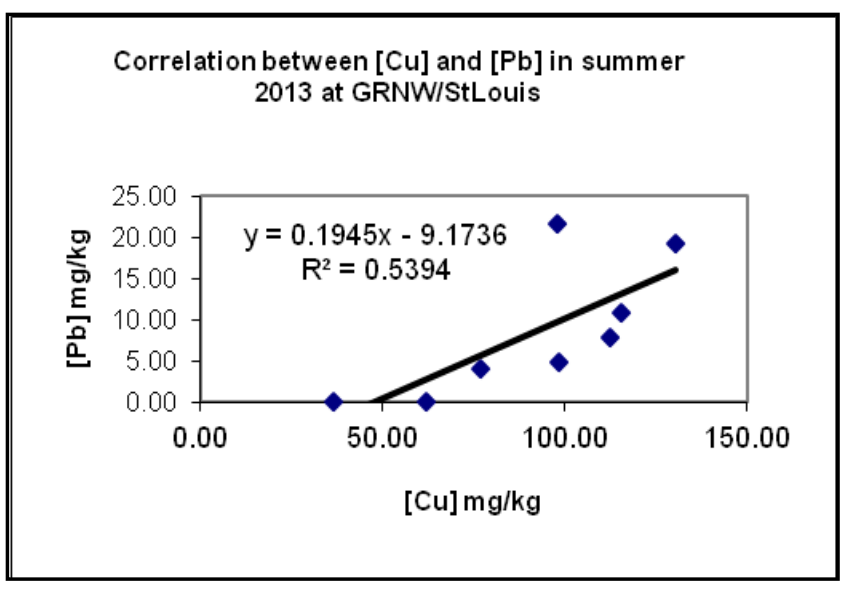

Figure 5. Correlations between $\mathrm{Pb}$ and $\mathrm{Cu}$ at GRNW in summer 2013

\section{Conclusion}

The contamination of GRNW estuarine sediments by $\mathrm{Cu}$, $\mathrm{Pb}$ and $\mathrm{Zn}$ was significant and considered to arise from brakedust, tyre wear, the use of leaded petrol and lubricating oils containing zinc additives and road furniture and potentially constitute a health hazard with increasing vehicles.

\section{Acknowledgements.}

Thanks to Vishwa Ramsahye, Aushima Boyjoo and Nehrroy Seechurn for assistance during sampling work and analysis of trace metals in sediment samples in the Chemistry Labs at the University of Mauritius and funds under Project R115.

\section{REFERENCES}

[1] P. Censi, S.E. Spoto, F. Saiano, M. Sprovieri, S. Mazzola, G. Nardone, S.I. Di Geronim, R. Punturo, D. Ottonello. Heavy metals in coastal water systems. A case study from the northwestern Gulf of Thailand. Chemosphere, 64:1167-1176, 2006

[2] R.T. Ramessur. Trace Metal Contamination in Urbanized Estuaries and Implications of Submarine Groundwater Discharge for Coastal Zone Management in Mauritius. In: Natural and Man Made Disasters Section-4: Chapter 16. Editors: Singh, K.K and Singh, A.K, Vol 1 pp329-342 Times Press, 2010

[3] R.T. Ramessur, K. Boodhoo, Z.B. Bissembur, J. Balgobin, A. 
Boyjoo. Investigation of lead and zinc in coastal sediments from the north west of Mauritius. J. Env Research and Development. Vol 5 No.3 pp 516-523, 2011

[4] R. J. Van Veen, P.B.M. Stortelder. Research on contaminated sediments in the Netherlands. In Wolf, K, Van de Brink, W.J and Colon, F. J (Eds). Contaminated soil. 1263-1275, 1988

[5] J. Sternbeck, A.A. Sjodin, K. Andreasson. Metal emissions from road traffic and the influence od resuspension- results from two tunnel studies. Atmospheric Environment 36: 4735-4744, 2002

[6] R.T, Ramessur S.J. Parry, K.E. Jarvis. Characterisation of some trace metals from export proceessing zone by using Inductively Coupled Plasma Mass Spectroscopy. Environmental International 326 Vol 24 No.7 pp 773-781, 1998

[7] R.T. Ramessur, S.J Parry, T. Ramjeawon. The Relationship of dissolved $\mathrm{Pb}$ to some dissolved trace metals ( $\mathrm{Al}, \mathrm{Cr}, \mathrm{Mn}$ and $\mathrm{Zn}$ ) and to some dissolved nitrate and phosphate in a freshwater aquatic system in Mauritius. Environmental International Vol 26 No. 4 pp 223-230, 2001

[8] R.T. Ramessur. Anthropogenic driven changes with focus to the coastal zone of Mauritius, South Western Indian Ocean. Regional Environmental Change. Vol 3 No. 13 pp 99- 106, 2002

[9] R.T. Ramessur, and T. Ramjeawon. Determination of $\mathrm{Pb}, \mathrm{Cr}$ and $\mathrm{Zn}$ from an urbanized river in Mauritius. Environment International. Vol 28 No. 4 pp 315-324, 2002

[10] R.T. Ramessur. Statistical comparison and correlation of $\mathrm{Zn}$ and $\mathrm{Pb}$ in estuarine sediments along the Western Coast of Mauritius. Environment International. Vol 30 No.8 pp 1039-1044, 2004

[11] R.T. Ramessur, K.Boodhoo, J. Balgobin, A. Aurelio. Statistical comparison between consecutive winter and summer concentrations in zinc and lead from sediments in a tropical urban estuary in Mauritius. Environmental Monitoring and Assessment. Vol 168 No. 1 pp 345-351, 2010

[12] V. M. Diagomanolin Farhang, M.Ghazi-Kkansari, N.Jafarzadeh. Heavy metals $(\mathrm{Ni}, \mathrm{Cr}, \mathrm{Cu})$ in the Karoon waterway river Iran. Toxicology letter 151: 63-67, 2004

[13] E.S Heinen De Carlo and S.S. Anthony. Spatial and temporarily variability of trace element concentrations in an urban subtropical watershed, Honululu, Hawaii. Applied Geochemistry 17: 475-492, 2002

[14] M.E. Pereira, A.C Duarte, G.E Millward, S.N Abreu, C. Vale. An estimation of industrial mercury stored in sediments of a confined area of the lagoon of Aveiro (Portugal). Water Sci. Tech., 37 (6-7), 125-130, 1998

[15] J.C. Rees, J. Ridgway, R.W.O.B Knox, G. Wiggans, N. Breward, Sediment-borne contaminants in rivers discharging into the Humber estuary, UK. Marine Pollution Bulletin, 37 (3-7), 316-329, 1998
[16] H.M. Fernandez, L.F.C Conti, S.R. Patchineelam. An assessment of the pollution of heavy metals in Jacarepagua basin, Rio de Janeiro, Brazil: A statistical approach. Environmental Technology, 15, 87-94, 1994

[17] B.D. Garg, S.H. Cadle, P.A. Mulawa, P.J. Groblicki, C. Laroo, G.A. Parr. Brake wear particulate matter emissions. Environmental Science and Technology 34 (21): 4463-4469, 2000

[18] MBor-Cheng Han. Relationship between copper speciation in sediments and bioaccumulation by marine bivalves of Taiwan, Elsvevier, 1995

[19] M. Oztürk, G. Ozözen, O. Minareci. E. Minareci. Determination of heavy metals in of fishes, water and sediment from the Demirköprü Dam Lake (Turkey). Journal of Applied Biological Sciences, 2(3): 99-104, 2008

[20] M. Bijlsma, A.L.S. Galione, P. Kelderman, G.J. Alaerts, I.A. Clarisse. Assessment of heavy metal pollution in inner-city canal sediments. Water Sicence and Technology Vol 33 No.6 pp 231-237, 1996

[21] G.W. Bryan, B. Langston. Bioavailability, accumulation and effects of heavy metals in sediments with special reference to United Kingdom estuaries: a review, Environmental pollution, Elsevier 76, pp 82-131, 1992

[22] C. Fernandes, A. Fontainhas-Fernandes, D. Cabral, M.A. Salgado. Heavy metals in water, sediment and tissues of Liza saliens from Esmoriz-Paramos lagoon, Portugal. Environ. Monit. Assess. 136: 267-275, 2008

[23] N. Breward, J.G. Rees, B. Rawlins, J.M. Weeks, T.M. Williams, J.R.W. Harris, N. Stevenson. Manual for contaminant flux assessment in tropical coastal environments. Volume 1: Guidelines. British Geological Survey, Overseas Geology Series, Technical report, WC/98/41, 56, 1998

[24] B.S. Miller, D.J. Pirie, C.J. Redshaw. An assessment of the contamination and toxicity of marine sediments in the Holy Loch, Scotland. Marine Pollution Bulletin, 40 (1), 22-35, 2000

[25] V.S. Shrivastava, R.B. Marathe C.P. Sawant. 'Detection of trace metals in surface sediment of Tapti River. Archives of Applied Science Research, 3(2): 472-476, 2011

[26] Q. Cui, N. Brandt , R. Sinha , M.E. Malmström. Copper content in lake sediments as a tracer of urban emissions: Evaluation through a source-transport-storage model. Science of the Total Environment 408: 2714-2725, 2010

[27] F. Ackermann, H. Bergmann, U. Schleichert. Monitoring of heavy metals in coastal and estuarine sediments - a question of grain - size: $<20 \mu \mathrm{m}$ versus $<60 \mu \mathrm{m}$. Environmental Technology Letters Volume 4 Issue 7, pp 317-328, 1983 